\title{
How do teachers facilitate mathematics learning in Indonesia during the COVID-19 pandemic? A rapid review
}

\author{
Ibnu Rafi*, Heri Retnawati, Ezi Apino, Munaya Nikma Rosyada \\ Department of Mathematics Education, Faculty of Mathematics and Natural Sciences, \\ Yogyakarta State University, Indonesia \\ *E-mail: ibnurafi789@gmail.com
}

\begin{abstract}
The Coronavirus disease (COVID-19) pandemic forces learning, including mathematics learning, to be carried out in online or distance mode. This situation is a challenge for teachers in facilitating mathematics learning because they are required to organize mathematics content and integrate it with certain learning technologies. In this article, we reviewed a total of 14 articles to describe how mathematics teacher in Indonesia facilitates online learning during the COVID-19 pandemic by focusing on types of technology used and reasons for choosing the technology, strategies used in integrating the technology with certain learning models or methods, ways of facilitating online discussion to construct knowledge, and assessments conducted as well as effects of the online learning facilitated by the teacher. Some implications for policy and practices are also provided in this article for improvement of online mathematics learning during the COVID-19 pandemic and may also after the pandemic is over in which it is possible to combine online and offline learning.
\end{abstract}

Keywords: COVID-19 pandemic, online mathematics learning, rapid review

\section{INTRODUCTION}

The COVID-19 pandemic that has occurred in Indonesia since March 2020 requires formal learning in schools and colleges to shift from face-to-face learning to online learning or distance learning. This condition raises its own challenges for schools, especially teachers, concerning how to facilitate online learning. The challenges faced by the teacher, specifically, relate to the knowledge of teachers in utilizing digital learning technology and integrating it with learning content to create meaningful learning (Churiyah et al., 2020; Lestiyanawati \& Widyantoro, 2020; Mailizar et al., 2020). Another challenge is related to technical matters, such as the unequal readiness of devices that support online learning and internet access, both from the teachers and students (Azzahra, 2020; Habibi et al., 2021).

Due to insufficient experience in dealing with conditions that may never have been expected in Indonesia, the learning that occurs tends to be one-way, in which the teacher facilitates students to learn through giving assignments. An example of this assignment is that students are asked to read learning material, understand worked-example, and work on practice questions. The study conducted by Churiyah et al. (2020) demonstrates that, in the initial period of the implementation of the distance learning policy in Indonesia, teachers tended to be oriented towards giving assignments to students without providing sufficient material explanations or other learning support, except asking students to read learning materials in books that students have. A learning activity like this happens in almost all lessons so that it is considered to cause more burden for students than when learning is carried out face-to-face at school. The burdens that arise on students are not only caused by learning that is oriented towards the assignment, but also due to students' low self-regulated learning (Churiyah et al., 2020). 
Responding to the challenges and problems of education in terms of the learning process during the initial period of the COVID-19 pandemic, the Indonesian government through the Ministry of Education and Culture of the Republic of Indonesia (2020) issued a policy that the focus of learning during the pandemic was directed at facilitating meaningful learning for students and equipping students with life skills without having to meet all learning requirements based on the present curriculum. Besides, the teacher is also expected to provide feedback, at least qualitative feedback, on the assignment or learning process carried out by students. In facilitating such learning, teachers are expected to keep considering the availability of access and learning facilitation that each student has. In response to this, the Indonesian government through the Ministry of Education and Culture has developed a learning portal called Rumah Belajar that can be used by teachers and students from early childhood education or Pendidikan Anak Usia Dini (PAUD) to senior high school. The learning portal provides facilities in the form of a learning management system (LMS) for conducting virtual learning, multimedia learning resources, question banks, and virtual laboratories. In addition, universities and various educational institutions also provide support to teachers in facilitating online learning through the provision of ongoing training or mentoring (e.g., Ariadhy et al., 2020; Aryani et al., 2020; Hidayati \& Mubarak, 2021; Safarati et al., 2020).

With the support of various parties who focus on the field of education and the spirit of teachers to always learn and innovate to support their students in learning, little by little teachers have been able to adjust to the conditions that are happening. This form of selfadjustment can be demonstrated by the use of quite varied learning technologies, such as utilizing learning management system (LMS) technology, edutainment, interactive learning materials or videos, and even using virtual meeting technology. In other words, teachers are constantly adapting to using various technologies that support online or remote learning, both in synchronous and asynchronous modes. When online learning facilitated by the teacher is carried out in asynchronous mode, the learning technology used must support the real-time learning experience (e.g., virtual meetings technology). This is different when online learning is carried out in an asynchronous mode where there is no demand that the technology used must allow real-time interactions even though the learning participants are in different places.

The approach used in learning a subject can be unique, especially when these subjects have different disciplines. For example, the learning approach used in facilitating students to learn mathematics will certainly be different from the learning approach used to facilitate students in learning languages or sociology. It is hoped that the difference in this approach is understood by every teacher. Now the challenge for teachers is to integrate this learning approach by utilizing digital learning technology amid the COVID-19 pandemic. In this case, the mathematics teacher has more challenges in terms of integrating mathematics, which is abstract, and even when taught face-to-face in schools, many students find it difficult to learn it compared to studying other subjects (Gafoor \& Sarabi, 2015; Langoban, 2020; Mulwa, 2015), with digital learning technology to facilitate distance mathematics learning.

Many previous studies have investigated students' views or perceptions of mathematics learning that teachers facilitated through distance learning during the COVID-19 pandemic in Indonesia (e.g., Balkist \& Agustiani, 2020; Mustakim, 2020; Pasehah et al., 2020). The descriptive study conducted by Mustakim (2020) with 30 students as respondents in one class at a public high school indicates that most students think that the mathematics learning process facilitated by the teacher is effective. Furthermore, the study also revealed that learning activities through discussion became the most popular strategy in online or distance mathematics learning. Even though the mathematics learning process, based on this study, is 
considered effective, students recommend that learning can also be carried out in a variety of ways, for example by virtual meetings which are, of course, accompanied by adequate support in terms of internet quota and connection. Meanwhile, a qualitative study with a phenomenological approach conducted by Pasehah et al. (2020) with six high school students as participants found that the students were less able to understand the learning material presented online through media in the form of PowerPoint, photos, or videos. They argue that understanding mathematics material when learning is carried out online is more difficult than when learning is carried out face-to-face in schools. In addition, even though students judge that Google Classroom is suitable for use in mathematics learning because of the ease of accessing it, assignment collection through Google Classroom is deemed complicated and there are no facilities provided by the teacher in Google Classroom for students to ask questions related to learning material that they do not understand.

Several previous studies have also succeeded in revealing the views or perceptions of mathematics teachers towards distance learning mathematics (e.g., Fakhrunisa \& Prabawanto, 2020; Mailizar et al., 2020). Mailizar et al. (2020) through their study shows that the inadequacy of knowledge, skills, and confidence in using digital learning technology is seen as an obstacle for mathematics teachers to facilitate distance mathematics learning in the initial period of the COVID-19 pandemic in Indonesia. The perspective of the mathematics teacher at the beginning of the pandemic period could of course have changed for the better because of the support from various parties as previously explained. Also, this change of perspective for the better can be shown through Septiani's (2020) study which found that mathematics teachers have maximized their creative abilities to facilitate students in learning mathematics through developing instructional videos, utilizing the Discord platform, utilizing Zoom for carrying out virtual meetings, and use of various platforms to carry out quizzes, such as Google Forms, Kahoot!, and Quizizz. Even a study conducted by Amelia et al. (2020) shows that teachers have been able to maximize the use of learning media such as Google Classroom, WhatsApp, and Zoom so that they can facilitate their students to have high mathematical resilience.

Based on the description of the distance learning process of mathematics from the perspective of students and teachers, we can say that students and teachers are sufficiently able to adapt to existing conditions. Teachers as facilitators have adjusted themselves by constantly innovating and increasing their competence in utilizing digital learning technology so that distance learning could encourage students to be enthusiastic about learning mathematics. However, based on the student's perspective, the distance learning process of mathematics can still be further improved. Therefore, this study was devoted to investigating the various mathematics learning processes facilitated by teachers in Indonesia during the COVID-19 pandemic.

\section{REVIEW FRAMEWORK}

Educational activities, one of which is reflected from the learning process at school, can be viewed as a system composed of components that are interrelated and support one another. These components are very diverse. However, in general, Biggs (1993) divides these components into three groups, namely presage, process, and product or outcome of learning. Group of presages of learning can be used to predict the learning process and ultimately the interaction between presage and process of learning can determine the product or outcome of learning. The presage of learning comprises of student components (e.g., learning style, prior knowledge and skills, motivation, and expectation towards the learning process that they are going to do) and learning environment components (e.g., teacher characteristics, learning 
model or strategy, learning content, organization of learning content, and assessment practices that the teacher intends to apply in the learning process). The group of the learning process includes components that are the realization of the models, methods, or strategies of learning and assessment that have been planned by the teacher which are then integrated with learning content by considering student characteristics. Lastly, learning products or outcomes reflect the extent or how well students master what they have learned. This product or outcomes of learning, if we relate it to the Kurikulum 2013, as the present national curriculum in Indonesia, represents the student's mastery of certain basic competences in a particular subject and school level.

The concept of learning activities proposed by Biggs (1993) is general, so it applies both to offline and online learning activities. In practice, online learning activities are not much different from offline learning activities. It is just that when learning is carried out online, the existence of digital technology is necessary, both as a medium for interaction between teachers, as an organizer of learning content, and as a means to manage a whole learning process. Garrison et al. (2000) introduced a conceptual framework regarding the three intersecting components that are needed to achieve a successful online or distance learning implementation. The three components are cognitive support, social support, and the learning structure or process. Cognitive support is related to students' ability to construct knowledge through communication facilitated through the use of technology in online learning. Social support relates to the involvement of each student in the learning environment to create an interaction that can support knowledge construction. Finally, the learning structure or process is related to how teachers process learning content and develop learning activities and assessments of student learning. Besides, this also relates to the way the teacher in presenting learning content that has been organized to students.

The concept proposed by Biggs (1993) has been used by several studies to examine the implementation of the learning process (e.g., Spelt et al., 2009). Regarding the concept of Biggs (1993) which is then integrated with the conceptual framework of online learning introduced by Garrison et al. (2000), this study seeks to investigate and describe the way teachers facilitate mathematics learning during the COVID-19 pandemic in Indonesia. The purpose of this study is further focused on describing the following four things, namely (1) the type of technology used by teachers and the reasons for choosing the technology; (2) teachers' methods and processes in integrating technology with learning content and models or strategies; (3) how teachers facilitate interaction between teachers and students and between students to construct knowledge; and (4) the way of the teacher in carrying out the assessment and the impact of the learning that is facilitated based on the results of the assessment. By conducting this study, we hope to gain an understanding of the mathematics learning process that other teachers might adopt in facilitating students to learn mathematics in an online or a distance learning environment and alternative improvements to the existing mathematics learning process.

\section{METHODS}

This study employed a rapid review approach. A rapid review is an approach used to describe the results of the synthesis from various kinds of literature, where the results of the synthesis are expected to assist certain parties in making decisions (Haby et al., 2016; Omer et al., 2020). This approach can be said to be a modified form of systematic review which makes it possible to implement it in less time and use less literature (Featherstone et al., 2015) than a systematic review. Furthermore, Haby et al. (2016) mentioned that modifications are often made to existing methods of the systematic review approach in conducting rapid reviews, 
some of which are English-only literature, ignoring gray literature, limiting literature search sources, and only involving one person to select literature or extract data.

The literature used in this study was searched through Google Scholar and Garuda (Garba Rujukan Digital). A literature search was carried out on February 23, 2021. Literature was limited to journal articles in Indonesian or English published in 2020-2021. A literature search was initiated by typing a keyword string associated with a Boolean operator "(proses OR process) AND (pembelajaran or learning) AND (matematika OR mathematics) AND Indonesia AND (pandemi OR pandemic) AND Covid" in the Google Scholar. From this initial step, 3270 search results were obtained. Since the focus of this study is a mathematics learning at the elementary to high school levels, the literature contains the words "mahasiswa" or "college" or "undergraduate" or "PAUD" or "TK" (kindergarten) was excluded. This process was done by adding "-mahasiswa -college -undergraduate -PAUD -TK" in the initial string of keywords. This process left 910 search results which were then manually checked based on the title and type of literature. The indicated literature, based on the title, is in the form of a review or theoretical study; report the results of a study that is not on learning mathematics subjects; development of learning products (learning kits or media); training program; program evaluation; exploration of the views, attitudes, motivations, or perceptions of teachers, students, or parents towards online mathematics learning; and analyzes of students' errors, difficulties, or mathematical abilities and not journal articles were excluded from the database of this study. This process left only 54 pieces of literature.

As for the search for literature in Garuda done on title and abstract using two strings of keywords. The first string of keywords was "pembelajaran matematika, pandemi", while the second string of keywords was "mathematics learning, pandemic". The first string of keywords produced 22 pieces of literature, while the second string of keywords only produced 1 piece of literature. After being selected by title, the remaining 14 pieces of literature need to be further examined based on the suitability of their contents to the focus of the study.

The remaining 68 pieces of literature (54 from Google Scholar and 14 from Garuda) were then re-evaluated to investigate possible duplication. From this evaluation, the remaining 67 pieces of literature were then evaluated based on the abstract and their main content, whether they met the focus and research questions. This evaluation resulted in 14 pieces of literature in the form of a journal article which were then used as the main source of review in this study. We then organized the literature that became the main source of this study by identifying the important ideas contained in the literature that correspond to the research questions. We then narratively synthesized the important ideas.

\section{RESULTS}

The literature totaling 14 journal articles that we reviewed in this study describes the learning process of mathematics in elementary to senior high school during the COVID-19 pandemic in Indonesia. The literature consists of four articles (Agustien \& Razak, 2020; Husna, 2020; Wiryanto, 2020; Wulandari et al., 2020) that focus on the learning process of mathematics at the elementary school level, six articles (Alfirahmadita \& Maarif, 2020; Harisuddin, 2020; Lutfiyah, 2020; Masdafni, 2020; Palgunadi et al., 2021; Susanto \& Yudanti, 2020) that focus on the learning process of mathematics at the junior high school level, and four articles (Djunaedy, 2020; Syamsuddin et al., 2020; Wahyuningrum \& Latifah, 2020; Yulianto, 2020) that focus on the learning process of mathematics at the senior high school level. 


\section{Types of technology used by the teacher to facilitate mathematics learning and the reasons for choosing the technology}

Based on a review of 14 existing journal articles, the results demonstrated that the types of technology commonly used by teachers in facilitating their students to learn mathematics during the COVID-19 pandemic in Indonesia were instant messaging platforms such as WhatsApp $(n=10)$ and Telegram $(n=1)$, learning videos $(n=8)$, virtual meeting platforms such as Zoom Meeting $(n=6)$ and Cisco Webex $(n=1)$, learning management system (LMS) platform in the form of Google Classroom $(n=5)$, online survey tool in the form of Google Forms $(n=3)$, and television $(n=2)$. The type of technology used by the teacher in facilitating students in learning mathematics remotely was chosen based on several considerations, both in terms of technical issues, student characteristics, and the potential of existing technology. Technical considerations such as lack of support for internet connections and availability of devices as well as a lack of understanding and mastery of parents from various learning technologies were the main reasons for teachers to use instant messaging platforms such as WhatsApp and Telegram and television to facilitate mathematics learning. When there was sufficient support from a technical point of view, teachers used a variety of learning technologies so that students do not feel bored with the learning process of mathematics and are more motivated in learning mathematics, starting from using an LMS in the form of Google Classroom, using Google Forms to conduct assessments, making learning videos that were even presented in animated form, or using virtual meeting platforms.

Furthermore, as mentioned earlier, teachers in choosing the type of technology to be used in remote mathematics learning are also influenced by student characteristics and advantages offered by a particular technology. The characteristics of students here are related to the learning objectives that are going to be achieved or it can also be related to the kind of competences that are going to be developed through the learning environment that the teacher wants to create. As an example, studies conducted by Agustien and Razak (2020) and Susanto and Yudanti (2020) showed that learning technology or media in the form of the video was used by teachers in facilitating remote mathematics learning because some previous studies have demonstrated the potential of videos that could be used to create effective and meaningful learning. Furthermore, Susanto and Yudanti (2020) stated that the selection of learning technology in the form of video is in accordance with the potential of this type of technology and the learning objectives to be achieved, namely developing students' understanding of the concepts of addition, subtraction, multiplication, and division operations of integers.

The review in this study also found that the use of technology to conduct virtual meetings is not always based on the potential of this type of technology in supporting the interactive learning process. Although some studies (e.g., Agustien \& Razak, 2020; Djunaedy, 2020; Syamsuddin et al., 2020; Yulianto, 2020) have reported that the use of virtual meeting platforms such as Zoom and Cisco Webex is based on the availability of opportunities to communicate interactively between teacher and students or among students as face-to-face learning in school, Wahyuningrum and Latifah's (2020) study results presented different things regarding the reasons for using a virtual meeting platform in the form of Zoom. Their study indicated that Zoom was only used by teachers as a complementary technology to other technologies, namely Google Classroom and WhatsApp. Zoom could be referred to as a complementing technology in this case because it would only be used by the teacher to explain certain learning material when students do not understand and have difficulty in solving exercise problems related to the material. 


\section{Teachers' methods and processes in integrating the technology with learning content and models or strategies}

The way of teachers in organizing mathematics learning content which is then integrated with certain learning models or strategies has certainly been adjusted to the type of technology used. Our study shows that each type of learning technology has its uniqueness that affects the overall mathematics learning process. This uniqueness also has its own consequences for what is constructed by students in the learning process and its impact on student competence.

When the way of the teacher in facilitating online learning was by utilizing technology only in the form of WhatsApp or other instant messaging platforms, in general, the strategies applied by the teacher could be classified into two types. The first strategy that the teacher did was to send learning material through the WhatsApp group and then asked students to read and understand the learning material. After that, the teacher provided the opportunity for students to ask questions to the teacher via the WhatsApp group regarding things in the learning material that they could not understand. When there are no more questions from students, the teacher then provided facilities for students to check their understanding of the existing learning material by giving assignments in the form of solving mathematics problems related to the learning material that students have just learned. Students were given a certain time to accomplish the assignment. When they have accomplished the assignment, they were required to send their work via WhatsApp to the teacher privately to be assessed. Unfortunately, the results of the assessment carried out by the teacher were not accompanied by qualitative feedback so that students could not use it to learn or do self-evaluation for improvement. The second strategy carried out by the teacher was to only give assignments in the form of solving questions related to certain materials without providing learning materials and explanations and opening question-and-answer activities for learning materials first. Strategies like this are possible when the teacher perceives that students can read and understand the learning material by themselves through various sources that they can reach.

Another alternative that teachers decide to maximize the use of WhatsApp to facilitate online mathematics learning was by positioning it as a complement or supporter of the use of other technologies (i.e., learning video, television, Google Forms, Google Classroom, and Zoom). When the teacher positioned WhatsApp as a supporting technology from the use of television, the method used by the teacher to facilitate mathematics learning was by allowing students to pay attention to the explanation of the material presented attractively in a program called Mantul (matematika manfaat betul or mathematics is very useful). Through this program, learning material is presented in an attractive manner where the material is packaged in the context of everyday life so that it is hoped that this can make it easier for students to understand the material. Besides, through such a context, students are also expected to be able to understand the application and importance of the mathematics material they are studying so that they are more motivated to learn mathematics. In the Mantul program, besides presenting an explanation of certain mathematical concepts and principles, it also provides examples of questions related to these concepts and principles and their step-by-step solutions which are expected to increase students' understanding of what they are learning. After students watch the Mantul program, the teacher asked students to work on the questions 
presented in the program or work on the questions given by the teacher in accordance with the material they have learned. When students have finished working on these questions, they are asked to send the results of their work to the teacher via WhatsApp.

When the teacher used WhatsApp as a supporting technology for the use of learning videos, the way of the teacher in facilitating mathematics learning was by sending the learning video to students via the WhatsApp group. These learning videos could be in the form of videos made by the teacher (see Harisuddin, 2020; Wiryanto, 2020) or videos available on YouTube (see Alfirahmadita \& Maarif, 2020) which not only contains an explanation of the concepts and principles of the related material but also contains questions and discussion of solutions. The videos presented to students were also packaged in various forms, including animation (see Masdafni, 2020). The learning content contained in the video was organized from the easiest or simplest things to the most difficult or complex things. In practice, teachers do not just provide learning videos for students to watch and understand. The teacher also provided learning support to students by explaining the learning material before giving learning videos to students or vice versa where the teacher provided explanations for things that have not been understood by students after they have watched the learning video.

When teacher employed a certain learning model to facilitate students in online mathematics learning, there were more than two types of learning technology used, where at least the teacher used the type of technology in the form of virtual meetings platform (see Agustien \& Razak, 2020; Djunaedy, 2020). The virtual meetings technology was not used in all phases of the implemented learning model. For instance, a study conducted by Djunaedy (2020) demonstrated that in problem-based learning, the virtual meeting platform in the form of Zoom was used by the teacher to facilitate students in carrying out discussion activities regarding the results of analysis and evaluation of factual problem solving presented in a worksheet that was uploaded to Google Classroom to gain an understanding of mathematical concepts and principles. The learning activities in other phases were carried out through WhatsApp and Google Classroom.

Our review also found that the technology for virtual meetings was only used in certain conditions. In other words, this type of technology is not entirely intended to facilitate students in constructing knowledge. As mentioned earlier, the specific conditions referred to here are conditions when students really could not understand the learning material even though it has been learned through WhatsApp or Google Classroom (see Wahyuningrum \& Latifah, 2020) or a condition in which the teacher intended to reinforce the concepts that students were learning (see Syamsuddin et al., 2020).

\section{How teachers facilitate interaction between teachers and students and among students to construct knowledge}

Because the type of technology commonly used by teachers to facilitate students in learning mathematics during the COVID-19 pandemic, based on the results of the review in this study, is instant messaging technology, the interactions that occurred during the learning process were dominated by interactions in the form of text, pictures, and voice messaging. This form 
of interaction could occur when the teacher explained certain learning material to students and then allowed students to ask questions that they did not understand. In addition, this interaction also occurred when the teacher facilitated students to discuss what they have learned from watching the Mantul program and solving the questions displayed on the program or questions given by the teacher as a form of assignment. Moreover, Yulianto (2020) described an interaction activity facilitated by the teacher, where students discussed with each other in solving a problem to construct knowledge, and the teacher as a facilitator played a role in providing corrections to the misunderstanding that students have.

The facilities provided by the teacher for students to interact both with the teacher and with other students when using virtual meetings technology are possibly more interactive and greater than when using instant messaging technology or LMS. In addition to finding things that are in line with this possibility, this study also finds things that are contrary to this possibility. Based on a review of the study results reported by Agustien and Razak (2020), Djunaedy (2020), and Palgunadi et al. (2021), we found that virtual meeting technology was used by teachers to facilitate interactive discussion activities among students to construct knowledge. The discussion activity was in the form of discussing a problem and its solution to gain an understanding of certain mathematical concepts, presenting results of students' works, giving responses to presentations made by one of the students when they found different findings, verifying student understanding, and reflecting on what the students have learned. However, research conducted by Wahyuningrum and Latifah (2020) demonstrated different findings that because the purpose of using Zoom was to simply explain things that were difficult for students to understand, as a consequence there was no interaction between teachers and students or among students.

\section{The way of the teacher in carrying out the assessment and the impact of the learning that is facilitated based on the results of the assessment}

In general, the assessments carried out by teachers in the mathematics learning process during the COVID-19 pandemic can be divided into two types as in the learning process before the pandemic occurred, apart from the midterm assessment and the end of semester assessment. First, the assessment was carried out at each meeting by giving assignments in the form of solving questions related to what the students have learned that day (e.g., Alfirahmadita \& Maarif, 2020; Harisuddin, 2020; Lutfiyah, 2020; Wiryanto, 2020; Wulandari et al., 2020). Second, the assessment was carried out when students have finished learning a certain basic competence (e.g., Agustien \& Razak, 2020; Harisuddin, 2020; Masdafni, 2020; Syamsuddin et al., 2020). The way of teachers in carrying out assessments and technology employed to administer tests were also quite diverse. When the assessment carried out by the teacher was the first type, students were given a task by the teacher to solve several questions after they have learned certain mathematical concepts or principles with learning facilities provided by the teacher such as watching learning videos, learning student worksheets and other learning materials available in LMS platform, discussing in virtual meetings, and watching the Mantul program on television. The test was administered by the teacher to students through WhatsApp group, Google Forms, or LMS platform such as Google Classroom. Student work results on assignments sent to the teacher via private messages using WhatsApp when the teacher did not utilize Google Forms or LMS. 
Of the 14 articles reviewed in this study, unfortunately, we did not have sufficient information regarding the detailed feedback provided by teachers to student work other than quantitative feedback of the form numeric marks or grades in the assessments that have been carried out. Lutfiyah (2020), through her study, pointed out that teacher provided feedback on student work on assignments given by the teacher after students learned by watching the Mantul program on television in the form of discussing solutions to each problem on the assignment via WhatsApp group on the same day as the day the assignment was given to students. However, the study did not describe in detail how the teacher discussed the solution to each existing problem; whether by involving discussions with students, where students are first allowed to propose an opinion on a solution to a problem then other students respond to it or the teacher immediately provides a solution to each existing problem then confirms students' understanding of the solution. In other studies, for instance, a study that was conducted by Wahyuningrum and Latifah (2020), the way that the teacher did in providing feedback on student work on an assignment for assessment was to provide step-by-step solutions to the problems on the assignment. Students were then asked to learn, detect, and make some corrections to the things that were wrong in their work by referring to the step-bystep solutions that have been provided.

Apart from the various obstacles that exist in the online mathematics learning process due to both technical and non-technical factors (e.g., minimum feedback given to students and difficulty in organizing learning content and strategies when the technology used was only instant messaging technology (Husna, 2020; Wiryanto, 2020)), the online mathematics learning that was facilitated by the teacher through the utilization of various types of learning technology provided some positive impacts on students' mathematical competences. Several studies (e.g., Agustien \& Razak, 2020; Djunaedy, 2020; Syamsuddin et al., 2020; Yulianto, 2020) have shown that virtual meetings technology, either used alone or supported by the use of other types of technology (e.g., LMS, learning videos, instant messaging technology) during the online mathematics learning process, can support students in developing problemsolving skills, learning achievement, critical attitude, being active in the learning process, and higher-order thinking skills (HOTS). In addition, several other studies (e.g., Alfirahmadita \& Maarif, 2020; Lutfiyah, 2020; Masdafni, 2020) have reported that the use of instant messaging technology in the form of WhatsApp or Telegram which functions as a support in the mathematics learning process that utilizes learning videos or the Mantul program can assist students to achieve standard-setting for certain basic competence.

\section{DISCUSSION}

This study aimed to describe how teachers facilitate mathematics learning in Indonesia during the COVID-19 pandemic. The first focus of the study was to describe the type of technology used by teachers and the reasons for choosing this type of technology. The results of the study have indicated that the type of technology commonly used in remote or online mathematics learning is instant messaging technology, for instance, WhatsApp and Telegram. The basis for selecting this type of technology is generally related to technical matters. From these results, we can say that instant messaging technology could be used more than just a medium for sending messages, where it could also be potential to be used by teachers to facilitate students in constructing knowledge of existing learning materials or achieving certain basic competences in mathematics subject.

Several previous studies have reported the potential of instant messaging technology to be employed to facilitate mathematics learning, even when the technology was used before the COVID-19 pandemic. For instance, a study conducted by Naidoo and Kopung (2016) has 
revealed that the use of WhatsApp could promote students' mathematical proficiency. This result could happen because of several things related to the advantages of using WhatsApp in addition to advantages in terms of ease of access to it. The advantage referred to here is related to the availability of opportunities for teachers to create meaningful mathematics learning (Naidoo \& Kopung, 2016). This meaningful learning could occur through constructive and collaborative learning activities where each student has the opportunity to share knowledge and involve in peer-tutoring activity in which students provide assistance or advice to other students in solving problems to construct knowledge with teacher guidance. Peer tutoring activity in mathematics learning has been widely proved by many studies (e.g., Alegre-Ansuategui et al., 2018; Alegre et al., 2019, 2020) to be beneficial for promoting students' academic achievement, both in primary and secondary school. Besides, the results of a study by Alegre et al. (2019) have indicated that the benefits of peer-tutoring can still be obtained even though it is carried out for less than 30 minutes. This indicates that if teachers can take advantage of instant messaging technology in online mathematics learning to facilitate peer-tutoring activities, the use of this technology can still support students to develop academic achievement in mathematics optimally even though learning is carried out in a shorter time than when it is carried out face-to-face at school. Another potential benefit of WhatsApp has been demonstrated by Jere et al. (2019) who suggested that the use of WhatsApp in mathematics learning makes it possible for teachers and students to conduct self-assessment and peer-assessment. Again, these two types of assessment are believed to be powerful in fostering students' mathematics competences in cognitive and affective aspects (Adediwura, 2012; Brignell et al., 2019; Mahayukti et al., 2017).

Through this review, we also revealed that teachers have used virtual meeting technology that allows interactive interaction between teachers and students, and among students like the learning process in schools, it is just that they are separated by space or different places. Although the results of the review showed that not all teachers use the technology properly for some reason, we believe that teachers have understood the potential of this type of technology that other types of technology such as LMS and instant messaging technology may do not have so that in the end it may have an impact on student learning outcomes.

Regardless of the type of technology used by the teacher in facilitating online mathematics learning, we believe that the learning outcomes that arise are not only influenced by the potential factors offered by the technology but are also greatly influenced by how the teacher organizes learning content including how it is presented and applying a particular learning method or model and then integrating the two things with the technology used. In other words, to achieve a certain goal in an online learning environment, of course, the existence of technology is indispensable, teachers need to carefully consider what kind of model or method should be used and also how to organize existing learning content, for example, whether to use a deductive or inductive approach (Rafi et al., 2020). Our review exposed that the available and used technology affects the way teachers implementing learning models or methods, facilitating discussion activity, conducting assessments, and providing feedback that ultimately affects learning outcomes. Again, regardless of the type of technology used by teachers, our review found that what teachers do may not fully facilitate the construction of knowledge by students themselves. This is due to the finding that in some learning processes, teachers prefer to explain the learning material and then give assignments for students to solve the questions, either for assessment or just for practice. Such learning practices, however, according to Mayer (Mayer, 2002), are more inclined towards rote learning which emphasizes knowledge acquisition rather than meaningful learning which emphasizes knowledge construction. Although rote learning in some cases brings its benefits for students, 
this type of learning approach could hinder students to succeed in solving problems outside the context that they learn from teacher explanations or explanations in the Mantul program.

\section{Implications for policy and practices}

The review conducted in this study shows that the type of technology commonly used by teachers in facilitating students to learn mathematics in online or remote mode is instant messaging technology. This type of technology is an option because of limitations in terms of devices, internet connections, and mastery of technology utilization. As a consequence, we suggest that teachers, students, parents, and certain educational institutions should not insist on mathematics learning to be carried out interactively using virtual meeting technology when conditions do not support the implementation of such activities. WhatsApp as an instant messaging platform has been shown by the previous study to be able to provide benefits in supporting the mathematics learning process as well as developing students' mathematical competences, both in cognitive and affective aspects when it is used appropriately. Therefore, we expect various parties, institutions, or organizations that have concerns in the field of education, especially mathematics education, to provide support for mathematics teachers in optimally utilizing an instant messaging platform such as WhatsApp in addition to providing support for teachers in utilizing more sophisticated types of technology, for example, GeoGebra and animated videos. Support for optimally utilizing WhatsApp here can be in the form of webinars for mathematics teachers discussing how to present mathematics learning content in an appropriate sequence; facilitate the implementation of discussion, peer-tutoring, self-assessment, and peer-assessment activities; and alternative solutions in overcoming the challenges of using WhatsApp in online mathematics learning. Naidoo and Kopung (2016) in their study argued that one of the challenges of utilizing WhatsApp in mathematics learning is to control students in asking for or responding to questions from teachers and other students so that students' attention is not divided and students do not feel overwhelmed by text or picture messaging.

Considering the results of reviews which demonstrated that in facilitating students to learn mathematics, teachers often give assignments to students to solve problems as an assessment or exercise and there is a finding that online mathematics learning is also possible to develop HOTS in addition to lower-order thinking skills (LOTS) as well, we provide a suggestion that might be used as an alternative to that form of assignment. Previous research suggests that to support students in developing HOTS, teachers could implement certain learning models such as problem-based learning (Jailani et al., 2017; Retnawati et al., 2018) and creative-problem solving (Apino \& Retnawati, 2019). However, implementing these learning models could be a challenge for teachers, especially when the technology that can be accessed by teachers and students is only instant messaging technology. Therefore, as an alternative solution to the existing challenge, we suggest teachers engage students in metacognitive activities. One of the metacognitive activities that can be done is asking students to take notes using their own words after watching the Mantul program on television, pose a question, write down the solution to the problem posed, and finally write a reflection on the difficulties or obstacles faced in carrying out this activity. Such activities could not only be used to facilitate HOTS but could also be used to obtain information related to how students learn and think (Pugalee, 2001) which might then be used by teachers to make improvements in facilitating students to learn in an online or remote environment.

Although the teacher's way of facilitating students to learn mathematics during the COVID19 pandemic in Indonesia may no longer be relevant to the way teachers do after the pandemic ends, the results of this study are still relevant when teachers want to facilitate 
mathematics learning that combines face-to-face learning in schools and online learning. This relevance is of course related to how teachers should do when creating an online mathematics learning environment such as when teachers implement learning strategies in the form of blended learning and flipped classrooms. Finally, when teachers are dealing with technology to support the mathematics learning process, of course, the teacher does not only need to understand how to use and utilize this technology, but the teacher is also urgent to have pedagogical and content competences or knowledge and their integration with technological competence or knowledge (Rafi \& Sabrina, 2019).

\section{Limitations and future directions}

Because the approach that we use in this study is a rapid review, as has been mentioned by several previous studies (e.g., Hind \& Sibbald, 2014; Omer et al., 2020), the limitations in this study are associated with the literature search strategy, the database used to obtain literature, and the type of literature used which is limited only to journal articles. These limitations may cause the results of this study to not adequately describe the way teachers in Indonesia facilitate mathematics learning during the COVID-19 pandemic, especially for cases when teachers, students, and parents have sufficient support for technical matters such as internet connections, and technological devices so that remote or online mathematics learning can be done interactively using certain applications such as Geogebra. Because in the present study we only use Google Scholar and Garuda to obtain literature, we suggest future studies to use other databases and employ a more systematic literature search strategy to obtain more comprehensive literature. Other than that, in the future, we also suggest to the other researchers to employ gray literature (e.g., conference proceedings, dissertations or theses, and government reports) and focus on a specific education level to acquire a better understanding of how teachers facilitate mathematics learning in which it may be influenced by student characteristics.

\section{CONCLUSION}

This rapid review has succeeded in identifying the technology used to facilitate mathematics learning along with considerations in choosing the technology, how teachers integrate the technology used with content and learning models or methods, how teachers facilitate discussions, and how teachers carry out assessments, in which these four things reflect a small part of the way teachers in Indonesia facilitate mathematics learning during the COVID-19 pandemic. Various technologies were used by teachers in facilitating online mathematics learning which was also accompanied by various ways to integrate these technologies with learning content, learning models or methods, and assessments. The way teachers facilitate learning mathematics revealed in this study hints at several issues of improvement that might be considered by teachers, policymakers, or educational authorities.

\section{REFERENCES}

\section{References marked with an asterisk indicate studies included in the rapid review}

Adediwura, A. A. (2012). Effect of peer and self-assessment on male and female students' self-efficacy and self-autonomy in the learning of mathematics. Gender and Behaviour, 10(1), 4492-4508. https://www.ajol.info/index.php/gab/article/view/76744

*Agustien, D., \& Razak, A. (2020). Efektivitas metode problem solving terhadap hasil belajar matematika kelas IV SD Islam Al-Azhar 47 Samarinda pada masa pandemi Covid-19 [The effectiveness of problem solving methods on the fourth grade mathematics learning 
outcomes of Islamic Elementary School Al-Azhar 47 Samarinda during the Covid-19 pandemic]. Al-Madrasah: Jurnal Pendidikan Madrasah Ibtidaiyah, 5(1), 39-53. https://doi.org/10.35931/am.v5i1.395

Alegre-Ansuategui, F. J., Moliner, L., Lorenzo, G., \& Maroto, A. (2018). Peer tutoring and academic achievement in mathematics: A meta-analysis. Eurasia Journal of Mathematics, Science and Technology Education, 14(1), 337-354. https://doi.org/10.12973/ejmste/79805

Alegre, F., Moliner, L., Maroto, A., \& Lorenzo-Valentin, G. (2019). Peer tutoring and mathematics in secondary education: Literature review, effect sizes, moderators, and implications for practice. Heliyon, 5(9), 1-8. https://doi.org/10.1016/j.heliyon.2019.e02491

Alegre, F., Moliner, L., Maroto, A., \& Lorenzo-Valentin, G. (2020). Academic achievement and peer tutoring in mathematics: A comparison between primary and secondary education. SAGE Open, 10(2), 1-9. https://doi.org/10.1177/2158244020929295

*Alfirahmadita, J., \& Maarif, S. (2020). Peran bahasa dalam komunikasi pembelajaran matematika secara online pada masa pandemi Covid-19 [The role of language in online mathematics learning communication during the Covid-19 pandemic]. Jurnal Pendidikan Matematika, 8(3), 153-167. https://doi.org/10.23960/mtk/v8i2.pp153-167

Amelia, R., Kadarisma, G., Fitriani, N., \& Ahmadi, Y. (2020). The effect of online mathematics learning on junior high school mathematic resilience during covid-19 pandemic. Journal of Physics: Conference Series, 1657(1), 1-8. https://doi.org/10.1088/1742-6596/1657/1/012011

Apino, E., \& Retnawati, H. (2019). Creative problem solving for improving students' higher order thinking skills (HOTS) and characters. In E. Retnowati, A. Ghufron, M. Marzuki, K. Kasiyan, A. C. Pierawan, \& A. Ashadi (Eds.), Character education for 21 st century global citizens: Proceedings of the 2nd International Conference on Teacher Education and Professional Development (INCOTEPD 2017) (pp. 249-256). Routledge. https://doi.org/10.1201/9781315104188

Ariadhy, S. Y., Nurohman, S., Arkum, D., Handini, W., \& Ferdiana, F. (2020). Pelatihan pambelajaran jarak jauh di era pandemi Covid-19 [Distance learning training in the era of the Covid-19 pandemic]. Anoa: Jurnal Pengabdian Kepada Masyarakat, 1(3), 220226. https://doi.org/10.1234/anoa.v1i3.13640.g9544

Aryani, D., Malabay, M., Ariessanti, H. D., \& Putra, S. D. (2020). Pelatihan pemanfaatan google classroom untuk mendukung kegiatan pembelajaran daring saat pandemi Covid 19 di SMPIT Insan Rabbani [Training on the use of google classrooms to support online learning activities during the Covid 19 pandemic at SMPIT Insan Rabbani]. Jurnal Abdidas, 1(5), 373-378. https://doi.org/10.31004/abdidas.v1i5.67

Azzahra, N. F. (2020). Policy brief no. 2 - Addressing distance learning barriers in Indonesia amid the covid-19 pandemic. Center for Indonesian Policy Studies. https://repository.cips-indonesia.org/media/309162-addressing-distance-learningbarriers-in-8326e326.pdf

Balkist, P. S., \& Agustiani, N. (2020). Responses of students with special needs to online mathematics leaning during pandemic. Journal of Physics: Conference Series, 1657(1), 


\section{1-7. https://doi.org/10.1088/1742-6596/1657/1/012031}

Biggs, J. B. (1993). From theory to practice: A cognitive systems approach. Higher Education Research and Development, 12(1), 73-85. https://doi.org/10.1080/0729436930120107

Brignell, C., Wicks, T., Tomas, C., \& Halls, J. (2019). The impact of peer assessment on mathematics students' understanding of marking criteria and their ability to self-regulate learning. MSOR Connections, 18(1), 46-55. https://doi.org/10.21100/msor.v18i1.1019

Churiyah, M., Sholikhan, S., Filianti, F., \& Sakdiyyah, D. A. (2020). Indonesia education readiness conducting distance learning in covid-19 pandemic situation. International Journal of Multicultural and Multireligious Understanding, 7(6), 491-507. https://doi.org/10.18415/ijmmu.v7i6.1833

*Djunaedy, R. P. (2020). Penerapan pembelajaran online dengan model problem based learning untuk meningkatkan keaktifan belajar matematika siswa kelas XI MM 3 SMKN 5 Malang [The application of online learning with a problem-based learning model to increase the activeness of learning mathematics class XI MM 3 SMKN 5 Malang]. Laplace: Jurnal Pendidikan Matematika, 3(2), 95-108. https://doi.org/10.31537/laplace.v3i2.376

Fakhrunisa, F., \& Prabawanto, S. (2020). Online learning in covid-19 pandemic: An investigation of mathematics teachers' erception. The 4th International Conference on Education and E-Learning, 207-213. https://doi.org/10.1145/3439147.3439179

Featherstone, R. M., Dryden, D. M., Foisy, M., Guise, J. M., Mitchell, M. D., Paynter, R. A., Robinson, K. A., Umscheid, C. A., \& Hartling, L. (2015). Advancing knowledge of rapid reviews: An analysis of results, conclusions and recommendations from published review articles examining rapid reviews. Systematic Reviews, 4(1), 1-8. https://doi.org/10.1186/s13643-015-0040-4

Gafoor, K. A., \& Sarabi, M. K. (2015). Nature of mathematics that impacts difficulties in learning it: A comparison of student perspectives on learning school subjects from Kerala. All India Association for Educational Research Annual Cum International Conference on Standards and Benchmarks for Excellence in Learning, Teaching and Research.

Garrison, D. R., Anderson, T., \& Archer, W. (2000). Critical inquiry in a text-based environment: Computer conferencing in higher education. The Internet and Higher Education, 2(2-3), 87-105. https://doi.org/10.1016/S1096-7516(00)00016-6

Habibi, A., Mukminin, A., Yaqin, L. N., Parhanuddin, L., Razak, R. A., Nazry, N. N. M., Taridi, M., Karomi, K., \& Fathurrijal, F. (2021). Mapping instructional barriers during covid-19 outbreak: Islamic education context. Religions, 12(1), 1-14. https://doi.org/10.3390/rel12010050

Haby, M. M., Chapman, E., Clark, R., Barreto, J., Reveiz, L., \& Lavis, J. N. (2016). What are the best methodologies for rapid reviews of the research evidence for evidence-informed decision making in health policy and practice: A rapid review. Health Research Policy and Systems, 14(1), 1-12. https://doi.org/10.1186/s12961-016-0155-7

*Harisuddin, M. I. (2020). Pembelajaran jarak jauh dimasa pandemi Covid-19 meningkatkan 
pemahaman konsep matematis siswa SMPN 2 Kotabaru [Distance learning during the Covid-19 pandemic increased students' understanding of the mathematical concepts of SMPN 2 Kotabaru]. Didaktik: Jurnal Ilmiah PGSD STKIP Subang, 6(2), 205-215. https://doi.org/10.36989/didaktik.v6i2.146

Hidayati, D., \& Mubarak, R. (2021). Effectiveness of teacher training using online media during covid-19 pandemic in Indonesia. Advances in Social Science, Education and Humanities Research, 526(1), 350-354. https://doi.org/10.2991/assehr.k.210212.076

Hind, J., \& Sibbald, S. L. (2014). Smartphone applications for mental health-A rapid review. Western Undergraduate Research Journal: Health and Natural Sciences, 5(1), 1-9. https://doi.org/10.5206/wurjhns.2014-15.16

*Husna, K. (2020). Proses pembelajaran matematika di Madrasah Ibtidaiyah Negeri 3 Langsa di tengah pandemi Covid-19 [The process of mathematics learning at Madrasah Ibtidaiyah Negeri 3 Langsa in the midst of the Covid-19 pandemic]. Pedagogik: Jurnal Ilmiah Pendidikan Dan Pembelajaran, 7(2), 144-155.

Jailani, J., Sugiman, S., \& Apino, E. (2017). Implementing the problem-based learning in order to improve the students' HOTS and characters. Jurnal Riset Pendidikan Matematika, 4(2), 247-259. https://doi.org/10.21831/jrpm.v4i2.17674

Jere, N. R., Jona, W., \& Lukose, J. M. (2019). Effectiveness of using WhatsApp for grade 12 learners in teaching mathematics in South Africa. In P. Cunningham \& M. Cunningham (Eds.), IST-Africa 2019 Conference Proceedings (pp. 1-12). IEEE. https://doi.org/10.23919/ISTAFRICA.2019.8764822

Langoban, M. A. (2020). What makes mathematics difficult as a subject for most students in higher education? International Journal of English and Education, 9(3), 214-220.

Lestiyanawati, R., \& Widyantoro, A. (2020). Strategies and problems faced by Indonesian teachers in conducting e-learning system during Covid-19 outbreak. Journal of Culture, Literature, Linguistic and English Teaching, 2(1), 71-82.

*Lutfiyah, L. (2020). Ketuntasan belajar matematika masa pandemi Covid-19 program televisi edukasi belajar dari rumah [Completeness of learning mathematics during the Covid-19 pandemic educational television program learning from home]. Laplace : Jurnal Pendidikan Matematika, 3(2), 142-150. https://doi.org/10.31537/laplace.v3i2.380

Mahayukti, G. A., Gita, I. N., Suarsana, I. M., \& Hartawan, I. G. N. Y. (2017). The effectiveness of self-assessment toward understanding the mathematics concept of junior school students. International Research Journal of Engineering, IT \& Scientific Research, 3(6), 116-124. https://doi.org/10.21744/irjeis.v3i6.577

Mailizar, M., Almanthari, A., Maulina, S., \& Bruce, S. (2020). Secondary school mathematics teachers' views on e-learning implementation barriers during the Covid-19 pandemic: The case of Indonesia. Eurasia Journal of Mathematics, Science and Technology Education, 16(7), 1-9. https://doi.org/10.29333/ejmste/8240

*Masdafni, M. (2020). Pembelajaran daring menggunakan video animasi meningkatkan hasil belajar matematika siswa kelas VIIC SMPN 1 Seberida [Online learning using animated videos improves mathematics learning outcomes of class VIIC students at SMPN 1 
Seberida]. Jurnal Pendidikan Tambusai, 4(2), 1752-1763.

Mayer, R. E. (2002). Rote versus meaningful learning. Theory Into Practice, 41(4), 226-232. https://doi.org/10.1207/s15430421tip4104_4

Ministry of Education and Culture of the Republic of Indonesia. (2020). Surat edaran nomor 4 tahun 2020 tentang pelaksanaan kebijakan pendidikan dalam masa darurat penyebaran coronavirus disease (covid-19) [Circular letter number 4 of 2020 on the implementation of educational policies during covid-19 pandemic].

https://www.kemdikbud.go.id/main/blog/2020/03/se-mendikbud-pelaksanaan-kebijakanpendidikan-dalam-masa-darurat-penyebaran-covid19

Mulwa, E. C. (2015). Difficulties encountered by students in the learning and usage of mathematical terminology: A critical literature review. Journal of Education and Practice, 6(13), 27-37.

Mustakim, M. (2020). Effectiveness of e-learning using online media during the Covid-19 pandemic in mathematics. Al Asma: Journal of Islamic Education, 2(1), 1-12.

Naidoo, J., \& Kopung, K. J. (2016). Exploring the use of WhatsApp in mathematics learning: A case study. Journal of Communication, 7(2), 266-273. https://doi.org/10.1080/0976691x.2016.11884907

Omer, U., Danopoulos, E., Veysey, M., Crampton, P., \& Finn, G. (2020). A rapid review of prescribing education interventions. Medical Science Educator, 31(1), 273-289. https://doi.org/10.1007/s40670-020-01131-8

*Palgunadi, N. P. P. D., Sudiarta, I. G. P., \& Ardana, I. M. (2021). Pengaruh model pembelajaran ALC berbasis e-modul terhadap kemampuan pemecahan masalah pada masa pandemi Covid-19 [The effect of the e-module-based ALC learning model on problem solving abilities during the Covid-19 pandemic]. Jurnal Ilmiah Pendidikan Matematika, 9(2), 114-125. https://doi.org/10.25273/jipm.v9i2.8286

Pasehah, A. M., Firmansyah, D., \& Adirakasiwi, A. G. (2020). Persepsi siswa SMA terhadap materi pembelajaran matematika secara online [High school students' perceptions of online mathematics learning material]. Jurnal Ilmiah Soulmath: Jurnal Edukasi Pendidikan Matematika, 8(2), 109-130. https://doi.org/10.25139/smj.v8i2.2903

Pugalee, D. K. (2001). Writing, mathematics, and metacognition: Looking for connections through students' work in mathematical problem solving. School Science and Mathematics, 101(5), 236-245. https://doi.org/10.1111/j.1949-8594.2001.tb18026.x

Rafi, I., Nurjannah, F. F., Fabella, I. R., \& Andayani, S. (2020). Peluang dan tantangan pengintegrasian learning management system (LMS) dalam pembelajaran matematika di Indonesia [Opportunities and challenges of integrating learning management system (LMS) in mathematics learning in Indonesia]. Jurnal Tadris Matematika, 3(2), 229-248. https://doi.org/10.21274/jtm.2020.3.2.229-248

Rafi, I., \& Sabrina, N. (2019). Pengintegrasian TPACK dalam pembelajaran geometri SMA untuk mengembangkan profesionalitas guru matematika [Integrating TPACK in geometry transformation learning in senior high school to develop mathematics teachers' professionality]. SJME (Supremum Journal of Mathematics Education), 3(1), 47-56. https://doi.org/10.35706/sjme.v3i1.1430 
Retnawati, H., Djidu, H., Kartianom, K., Apino, E., \& Anazifa, R. D. (2018). Teachers' knowledge about higher-order thinking skills and its learning strategy. Problems of Education in the 21st Century, 76(2), 215-230. https://doi.org/10.33225/pec/18.76.215

Safarati, N., Rahma, R., Fatimah, F., \& Sharfina, S. (2020). Pelatihan inovasi pembelajaran menghadapi masa pandemic Covid-19 [Learning innovation training in facing the Covid-19 pandemic]. Communnity Development Journal, 1(3), 240-245. https://doi.org/10.31004/cdj.v1i3.937

Septiani, R. (2020). Kreativitas guru dalam pembelajaran matematika kelas IV di masa pandemi Covid-19 (Studi deskriptif kualitatif pada guru kelas IV sekolah dasar) [Teacher creativity in learning mathematics in grade IV during the Covid-19 pandemic (Qualitative descriptive study of grade IV primary school teachers)] [Bachelor's thesis, Universitas Pendidikan Indonesia, Bandung]. http://repository.upi.edu/57477/

Spelt, E. J. H., Biemans, H. J. A., Tobi, H., Luning, P. A., \& Mulder, M. (2009). Teaching and learning in interdisciplinary higher education: A systematic review. Educational Psychology Review, 21(4), 365-378. https://doi.org/10.1007/s10648-009-9113-z

*Susanto, L. A. W., \& Yudanti, E. (2020). Efektivitas video pembelajaran matematika kelas VII SMP pada konsep operasi bilangan bulat [The effectiveness of seventh grade junior high school mathematics learning videos on the concept of integer operations].

Primatika: Jurnal Pendidikan Matematika, 9(2), 101-110. https://doi.org/10.30872/primatika.v9i2.371

*Syamsuddin, S., Ahmad, H., \& Afriani, A. (2020). Media pembelajaran online terhadap kemampuan berpikir tingkat tinggi matematika di tengah pandemi Covid-19 [Online learning media for higher-order mathematical thinking skills in the midst of the Covid19 pandemic]. Pepatudzu: Media Pendidikan dan Sosial Kemasyarakatan, 16(1), 41-50. https://doi.org/10.35329/fkip.v16i1.659

*Wahyuningrum, A. S., \& Latifah, T. (2020). Investigating mathematical conversation in remote learning of mathematics during the covid-19 pandemic. Jurnal Riset Pendidikan Matematika, 7(2), 148-162. https://doi.org/10.21831/jrpm.v7i2.34841

*Wiryanto, W. (2020). Proses pembelajaran matematika di sekolah dasar di tengah pandemi Covid-19 [The process of learning mathematics in elementary schools in the midst of the Covid-19 pandemic]. Jurnal Review Pendidikan Dasar: Jurnal Kajian Pendidikan Dan Hasil Penelitian, 6(2), 125-132. https://doi.org/10.26740/jrpd.v6n2.p125-132

*Wulandari, M. A., Arga, H. S. P., Kelana, J. B., Altaftazani, D. H., \& Ruqoyyah, S. (2020). Analisis pembelajaran "daring" pada guru sekolah dasar di era Covid-19 [Analysis of "online" learning for elementary school teachers in the Covid-19 era]. Jurnal Ilmiah P2M STKIP Siliwangi, 7(2), 164-168. https://doi.org/10.22460/p2m.v7i2p\%25p.2002

*Yulianto, D. (2020). Pengaruh pembelajaran daring pengguna platform digital terhadap pemecahan masalah matematis dan sikap kritis siswa di MA Daar El Qolam [The influence of online learning using digital platform users on solving mathematical problems and critical attitudes of students at MA Daar El Qolam]. Symmetry: Pasundan Journal of Research in Mathematics Learning and Education, 5(1), 107-128. https://doi.org/10.23969/symmetry.v5i1.2790 